\title{
Accounting for Biodiverse Wildlife Corridor Plantations
}

\author{
Claire A Horner (University of Tasmania) \& Neil Davison (Greening Australia Tasmania)
}

\begin{abstract}
Purpose: This paper explores the feasibility of implementing the Natural Inventory Model (NIM) developed by Jones $(1996 ; 2003)$ in biodiverse wildlife corridor plantations, from an NGO's perspective.

Design: Undertaking the first cycle of an action research approach, the project involves collaboration with Greening Australia (Tasmania) (GAT). GAT is endeavouring to establish native wildlife corridors throughout the Tasmanian midlands, using science-based biodiverse plantations. The majority of the areas identified by GAT as essential for the establishment of these wildlife corridors are on privately owned land, primarily used for agricultural purposes. This paper explores whether stewardship of the land 'sacrificed' by landowners may be demonstrated via the quantification and communication of improvements in biodiversity using the NIM.
\end{abstract}

Findings: Results suggest that the existing NIM is impractical for use by an NGO with limited resources. However, with some adaptations incorporating science-based measurements, the NIM can be used to account for biodiverse wildlife corridor plantations.

Practical Implications: The findings have implications for not-for-profit, corporate and government sectors in terms of how accounting may facilitate the quantification and communication of conservation and restoration efforts.

Social Implications: Biodiversity loss is now considered to be a greater threat to the planet than climate change. Efforts to account for biodiversity are consistent with the UN 2030 Sustainable Development Agenda and the Australian Government's 'Biodiversity Conservation Strategy' (2010).

Originality: Whilst prior studies have successfully implemented the NIM using secondary data, this is the first known to test the feasibility of the model using primary data in collaboration with an NGO.

\section{Introduction}

With the passing of each day approximately 14,000 hectares of forests are lost globally, net of reforestation (Worldometers, 2018). Human beings dominate the planet and scientists estimate that if we continue at our current rate of resource consumption many of the biological resources that we presently take for granted, and indeed depend upon for survival, will be irretrievably lost within just a few generations (Barnosky et al., 2012). Urgent action is needed if human life, as we know it, is to be sustained.

This paper reports upon the outcomes of one attempt to respond to this call for action. In doing so we use a participant action research approach (Susman \& Evered, 1978), underpinned by environmental stewardship theory to inform the refinement of an established accounting 
technique for accounting for biodiversity, namely the Natural Inventory Model (NIM) (Jones, 1996; 2003). By empirically testing the NIM we contribute to the aims of this special issue by exploring how the current challenge of accounting for Sustainable Development Goal (SDG) 15 (Life on Land) may be overcome, and contribute to an understanding of how reporting against this goal may be undertaken. Through collaboration with a non-government organisation (NGO), our interdisciplinary approach demonstrates how accounting can contribute to conservation and ecosystem management (Feger \& Mermet, 2017; Cuckston, 2018). We begin our literature review by providing the contextual background and motivations for the study, followed by an overview of the NIM. The evolution of accounting for biodiversity is then discussed, before considering the role of environmental stewardship theory.

\section{Background and Motivations}

In October 2010 the United Nations declared 2011-2020 to be the "Decade on Biodiversity", resulting in an intergovernmental agreement to implement the Convention of Biological Diversity's Strategic Plan for Biodiversity 2011-2020 (Adler, Mansi, Pandey \& Stringer, 2017; Convention on Biological Diversity (CBD), 2018). The objectives of the CBD are to conserve biological diversity, ensure the sustainable use of biodiversity, and the fair and equitable sharing of the benefits arising out of the use of genetic resources (CBD, 2018). This is consistent with the UN 2030 Agenda for Sustainable Development, particularly SDG 15 (Life on Land), which aims to "protect, restore and promote sustainable use of terrestrial ecosystems, sustainably manage forests, combat desertification, and halt and reverse land degradation and halt biodiversity loss" (United Nations, 2019). The SDGs provide an opportunity to reignite debates around accounting's contribution to sustainable development and emphasise the potential for empirical interdisciplinary research (Bebbington \& Unerman, 2018).

Australia has been identified as one of 17 mega-diverse wildlife countries in the world (Adler et al., 2017), yet holds the dubious record for the highest mammal extinction rate globally (Australian Wildlife Conservancy, 2013) and is ranked fourth in the world for extinct and critically endangered species (Akhtar-Khavari et al., 2019). In the eastern temperate zone, an estimated $90 \%$ of native vegetation has been removed for human habitation, industry and transport (CBD, 2018), and Australia's extinction record is being further exacerbated by increased urbanisation and large resource extraction approvals (Akhtar-Khavari et al., 2019). As a signatory to the CBD and a State Member of the International Union for Conservation of Nature (IUCN) (IUCN, 2020), the Australian government released "Australia's Biodiversity Conservation Strategy 2010-2030" (Commonwealth of Australia, 2016), recently revised as “Australia's (draft) strategy for nature 2018-2030" (Commonwealth of Australia, 2017). Under the revised draft strategy, the goals are to: "build and share knowledge, care for nature in all its diversity, [and] connect all Australians with nature" (Commonwealth of Australia, 2017:9). In achieving these goals, the objectives include:

- Empower Australians to be active stewards of nature

- Increase Australians' understanding of the value of nature

- Respect and maintain traditional ecological knowledge and stewardship of nature 
- Improve conservation management of Australia's landscapes, seascapes and aquatic environments

- Maximise the number of species secured in nature

- Use and develop natural resources in an ecologically sustainable way

- Increase knowledge about nature to make better decisions

- Share and use information effectively

- Effective measurement to demonstrate our collective efforts (Commonwealth of Australia, 2017:9)

As Australia's only island state, Tasmania is in a unique position with respect to the implementation of the Commonwealth's proposed "strategy for nature", which requires collaboration between "businesses, governments, academia, non-government organisations, landowners, Aboriginal and Torres Strait Islander custodians and the general community" (Commonwealth of Australia, 2017:14). Tasmania has a rich and somewhat chequered past in terms of environmental stewardship, the results of which allow it to lay claim to the establishment of the world's first 'green' political party (Milne, 2006). Of relevance to the current study, the Tasmanian Midlands have been identified by the Australian Government as a national biodiversity "hotspot" (Department of the Environment and Energy, 2018). Within this region there are 32 nationally threatened species and over 180 plants and animals listed as threatened at state level. This area was one of the first cleared for agriculture in Australia and is still predominantly utilised for agricultural and plantation forestry purposes, with widespread land clearing resulting in fragmented native land habitats (Department of the Environment and Energy, 2018).

In response to this issue, Greening Australia Tasmania (GAT) ${ }^{1}$ have embarked on a 20 -year project to build biodiverse wildlife corridor plantations throughout the Tasmanian Midlands. One thousand hectares of new habitat have already been created, with the ultimate goal of recreating over 6,000 hectares of new habitat. This project involves collaboration with a number of stakeholders, including private landholders, and government (Greening Australia, 2018). Issues identified by GAT in undertaking this project are associated with difficulties in quantifying the value associated with these biodiverse plantations, and communicating this value to private landholders and government funding bodies. Difficulties in communicating the value of science-based conservation strategies have been acknowledged in the literature, and has been suggested that accounting methods may assist in addressing this problem (Lobley, Saratsi, Winter \& Bullock, 2013; Ferger \& Mermet, 2017). Therefore, this paper reports upon the first cycle of an action research study exploring the feasibility of using the NIM developed by Jones $(1996 ; 2003)$ to account for biodiverse wildlife corridor plantations. An overview of the NIM is provided in the following section.

\footnotetext{
${ }^{1} \mathrm{GAT}$ is the Tasmanian division of Greening Australia, an Australia-wide conservation NGO. Other agencies involved in conservation in Australia include, (but are not limited to) Australian Wildlife Conservancy; Bush Heritage Australia; Nature Conservancy; Tasmanian Land Conservancy; and Trust for Nature (Department of Agriculture, Water and the Environment, 2020).
} 


\section{The Natural Inventory Model}

One of the problems underlying accounting for biodiversity relates to technical difficulties, particularly how to record biodiversity (Jones \& Solomon, 2013). The NIM (displayed in Figure 1) was developed by Jones (1996) as a method of overcoming this difficulty in accounting for, and reporting upon biodiversity. The model is implemented in three stages, the first involving the establishment of the acreage and habitats and undertaking a natural inventory. The second stage involves a valuation of the non-critical habitats at either a market or amenity value, complemented by an ecological grading. The final stage requires the results to be aggregated and published in summary form (Jones, 1996). In undertaking the first cycle of the action research we focused on the first stage of the NIM, a more detailed discussion regarding the requirements of which is provided below.

[Figure 1 about here]

In undertaking the natural inventory, the NIM provides six levels of levels of inventory that could be accounted for (Jones, 1996):

Level 1: Categorization by habitat type and natural capital status. This requires the identification of habitats as being either critical, non-critical (sustainable) or selfsustaining. Critical habitats would likely include sites of specific scientific interest, environmentally sensitive areas, national parks \& nature reserves.

Level 2: Inventory of listed and protected flora and fauna (i.e., critical natural capital) by species and by total population on all habitats. This requires a record of critical species on both critical and non-critical habitats by species and in total. Critical species are those classified as being rare, endangered or threatened.

Level 3: Inventory of critical habitats flora and fauna by species. This requires the identification of the species (both critical and non-critical) present in the critical habitats, thus giving a general qualitative overview of a site's importance.

Level 4: Inventory of critical habitats flora and fauna by total population. This provides a more detailed quantitative assessment of the habitat by identifying population numbers of each species (both critical and non-critical).

Level 5: General inventory of flora and fauna by species. This replicates Level 3 but for both critical and non-critical habitats.

Level 6: General inventory of flora and fauna by total population. This replicates Level 4 but for both critical and non-critical habitats, and Jones (2003) suggests would be nearly impossible to undertake in practice.

The NIM addresses the issues identified in the Commonwealth of Australia (2018) "strategy for nature" by identifying critical habitats and measuring associated key species. This in turn contributes to the objective of improving knowledge to inform better decision making in terms of the allocation of scarce resources. By quantifying biodiversity, we will not only be able to 
increase awareness of the positive impacts of biodiverse plantations, but also potentially provide an incentive to landholders in terms of 'sacrificing' their land. Communication is particularly important for engaging with landholders, given that they may not automatically understand the benefits that could accrue to them as a result of increased biodiversity on their land (Lobley et al., 2013). From an accountability perspective it is imperative that stakeholders view this in terms of stewardship for both present and future generations, which is consistent with the rhetoric espoused by the Australian Government in their conservation strategy.

The NIM has been successfully implemented in several international studies (Jones, 2013; Siddiqui, 2013), as well as in an Australian context (Hossain, 2017). However, the Australian study relied on secondary data that facilitated only a partial construction of an inventory of natural assets (Hossain, 2017). Furthermore, prior studies have examined the effectiveness of the model from an accounting and reporting perspective, relying on the availability of existing data. Therefore the first stage of this action research cycle explored the feasibility of the NIM from a user perspective by collaborating with an NGO to collect primary data, to determine whether the model is useful for assessing the value of their efforts to restore natural habitats, making it the first of its kind both nationally and internationally. In understanding how accounting may contribute to the sustainable management of ecosystems (Feger \& Mermet, 2017), it is useful to first reflect on how accounting has evolved to encompass biodiversity, which is discussed in the following section.

\section{The Evolution of Accounting for Biodiversity}

The practice of accounting has been criticised for its support of capitalist and economic values (Hines, 1989), failing to encourage socially and environmentally responsible behaviour (Lawrence, Botes, Collins \& Roper, 2013), and for its role in the degradation of the natural environment (Bebbington, Gray, Thomson \& Walters, 1994). However, the late 1980s and early 1990s saw the emergence of a school of thought suggesting ways in which accounting should play a role in re-orienting organisational activities to the environment by accounting for environmental impacts, which was supported not only by accounting academics, but also accounting practitioners, and business and political communities alike (Bebbington et al., 1994). This resulted in a growing body of literature on the importance of accounting for the environment, with environmental management accounting now considered a discipline in its own right (Schaltegger, Gibassier \& Zvezdov, 2013) in which it is acknowledged that accounting is not just about financial quantification (Feger et al., 2018), and is increasingly seen as more than a merely technical or instrumental activity (Miller \& Power, 2013). Due to issues identified with assigning monetary values to ecosystems (Ferger \& Mermet, 2017) various sustainability accounting methods have been proposed (Lamberton, 2005). In particular Bebbington (1997) discusses the importance of biodiversity from an environmental accounting perspective, and proposes sustainability assessment models as a viable alternative to costbenefit analysis (Bebbington, Brown \& Frame, 2007).

Whilst the global human population of 7.6 billion people represents only $0.01 \%$ of all life on the planet, humanity has caused the loss of $83 \%$ of all wild mammals and $50 \%$ of plants 
(Carrington, 2018). However, despite the erosion of the world's biodiversity being widely recognised as one of the greatest threats to the planet, until recently there was very little work exploring the role of accounting in enhancing or protecting biodiversity (Jones \& Solomon, 2013). Whilst concerns have been expressed regarding the anthropocentric potential to 'capture' the environment in an attempt value nature (Gray, Walters, Bebbington \& Thompson, 1995; Hines, 1991), others have suggested that accounting can play an active role in conservation by organising the world in ways that preserve wildlife (Cuckston, 2018), with inadequate accounting methods being better than none at all (Jones \& Solomon, 2013). Perhaps in part due to the plethora of reasons put forward as to why we should, and should not account for biodiversity (Jones \& Solomon, 2013), there has been a rapid rise in the accounting literature in the number of papers concerned with the issue of biodiversity (Cuckston, 2018).

Within the biodiversity related accounting literature, two distinct themes have emerged. The first is concerned with incorporating biodiversity in existing social and environmental accounting mechanisms, such as corporate sustainability reporting. The second looks instead at existing biodiversity conservation efforts and explores the role of accounting in these efforts (Cuckston, 2018). Within this second stream the importance of interdisciplinary research is emphasised, with engagement with diverse disciplines being essential to revealing social, political and institutional challenges (Feger el al., 2018). It has been suggested that accounting has enormous potential contribute to conservation science (Feger et al., 2018) and to provide non-financial accounts of the biosphere (Gray, 1992). An interdisciplinary approach to biodiversity conservation with collaboration between conservation and accounting research is essential (Jones \& Solomon, 2013; Feger et al., 2018). However, whilst conservation organisations potentially offer rich sites for research into how accounting plays a role in achieving biodiversity conservation, there has been surprisingly little research on the organisations that are dedicated to conservation (Cuckston, 2018).

Therefore, building on the seminal work of Jones $(1996 ; 2003)$ this study also focuses on a case where land is being actively managed for conservation by an NGO, and goes further to consider the ways in which accounting can contribute to conservation goals and practices. In this way the study may demonstrate how accounting provides the potential for accounting for biodiversity to become force for conservation (Cuckston, 2018). Consistent with the Australian Government's Strategy for Nature (2017) and the prior literature (Jones, 2003), the action research study is conducted through the lens of environmental stewardship theory, which is discussed in the following section.

\section{Environmental Stewardship Theory}

The concepts of 'land' and 'landscape' are intellectually, politically and ethically contested (Barry \& Smith, 2008), and a researcher's perspective on the ethics on 'accounting for nature' may differ according to their philosophical perspective (Gray, 1992). This is further complicated by differing views on what nature and the natural environment actually are, and the way in which humans interact with them (Laine, 2010). Gray (1992) criticises prior environmental proposals as being accompanied by 'theoretical flacidity', and it has been argued 
that by consigning accountability to free market mechanisms, environmental accounting frameworks may in fact contribute to the destruction of the natural world that they are intended to protect (Lehman, 1999). Similarly, Cuckston (2018) states that accounting research has so far lacked the theoretical rigour necessary to make a significant impact on conservation efforts. He argues that in order to provide insights that are useful to conservation, accounting researchers must move beyond traditional accounting tools to engage with broader conservation and human-nature relations research (Cuckston, 2018). However, whilst the potential for accounting to contribute to conservation has been recognised (Feger et al., 2018), collaborative research between the fields of conservation science and accounting has until recently been almost non-existent (Feger \& Mermet, 2017).

Given the conflicts in the prior literature regarding approaches to accounting for the environment, it is crucial for anyone attempting to account for biodiversity to make a decision regarding which philosophical perspective they espouse (Jones \& Solomon, 2013). The use of action research challenges the researchers to consider possible conflicts between their values as scholars compared to their values as activists (Somekh and Zeichner, 2009). However, the urgency of the present environmental crisis eliminates this potential conflict.

The theoretical underpinning of this paper is that of environmental stewardship, which is often used to brand policies (Mathevet, Bousquet \& Raymond, 2018) and is consistent with the Australian Government's Strategy for Nature (2017), and the prior literature (Jones, 2003). The concept of stewardship is receiving increasing attention in the environmental sciences and conservation literature, particularly the agri-environmental field (Mathevet et al., 2018). Stewardship originates from cultural traditions and religions across the world, and has evolved from describing a land ethic of care to take on a range of meanings that differ according to landscape values and land management activities (Mathevet et al., 2018). Whilst one of the primary objectives of Strategy for Nature is to "[e]mpower Australians to be active stewards of nature" (Commonwealth of Australia, 2017:9), the Strategy fails to explicitly define what is meant by 'stewardship'. Therefore, for the purposes of this study stewardship is defined "the wise and responsible use of natural resources [to] support social-ecological resilience and human wellbeing" (West, Haider, Masterson, Enqvist, Svedin \& Tengö, 2018:30), which is consistent with the suggestion in the Strategy for Nature that "stewardship of nature can contribute to Australia's nature conservation objectives and also build the health and resilience of our society, businesses and economy" (Commonwealth of Australia, 2017:10). Stewardship is considered to be both interdisciplinary and transdisciplinary in that it allows researchers from different backgrounds to work together with non-researchers on areas of shared concern and is based on a framework of care, knowledge and agency (West et al., 2018). Thus, landowners working with NGOs to create wildlife corridor plantations on agricultural land can be seen as evidence of stewardship (West et al., 2018).

Environmental stewardship is based on the understanding that landowners are stewards of the natural environment, and should account for their use of the natural environment accordingly. Stewardship behaviour is motivated predominantly by intrinsic and pychological factors (Dumay, La Torre \& Farneti, 2018), and an account of this behaviour may be provided for both altruistic and self-interested motives simultaneously (Jones, 2003). Therefore, it is important 
to acknowledge that this study is underpinned by a deep-green perspective. A deep-green perspective is one that places the environment at the centre of the equation, acknowledging that this equation is the result of a human analysis and thus privileges humankind (Gray, 1992). This is an important distinction and has implications for the development of the research question and research methods discussed below, because whilst the participants in the action research (the accountant, and the ecologist) may hold personal values more closely aligned with 'deep ecology' (that the natural environment has intrinsic value in its own right, regardless of anthropocentric viewpoints (Gray, 1992)), the nature of the study requires the privileged position of humans and their ability to contribute to and benefit from restoration ecology to be recognised.

Consistent with Cuckston (2018) this paper examines how accounting may contribute to existing conservation activities undertaken by an NGO, with communication playing an important role in environmental stewardship (Jones \& Solomon, 2013). Therefore, the following research question is driven by our conceptual and theoretical understanding of the world, and is derived from an interdisciplinary approach to research:

Can the Natural Inventory Model be used to account for biodiverse wildlife corridor plantations, from an NGO's perspective?

Action research was undertaken to determine the feasibility of using the NIM for accounting for biodiverse wildlife corridor plantations. This approach is driven by the values of the researchers, and their recognition of the urgency of the research problem. Whilst positivist research is concerned with what can be proven, and interpretivist research is concerned with what is interesting, action research is concerned with what is useful (Coghlan \& Shani, 2018).

\section{Methodology}

Action research was conceptualized by Kurt Lewin in 1946 as an approach to research which combines critical theory generation with changes to the social system in which the researcher operates (Susman \& Evered, 1978). The most commonly cited definition of action research is that it

aims to contribute both to the practical concerns of people in an immediate problematic situation and to the goals of social science by joint collaboration within a mutually acceptable ethical framework (Rapoport, 1970:499 cited in Susman \& Evered, 1978:587).

The aims of action research are thus to respond to the concerns of the researchers regarding a social issue that requires collaboration, making the immediacy of the identified issue an essential element of the research process (Susman \& Evered, 1978). Action research is a cyclical process involving five phases, which are necessary for the definition but not the implementation of the action research process (Susman \& Evered, 1978). The action research cycle has been represented in various ways in the extant literature and to varying degrees of complexity (e.g. Paisey \& Paisey, 2005; Cunningham, 2008; Curtis, 2017). The approach we adopted is consistent with Curtis (2017) and is displayed in Figure 2. 
[Figure 2 about here]

The stages of action research according to this cycle include recognizing a need for change, developing an action plan, implementing the action plan, observing and evaluating the consequences, and making sense of $\&$ sharing lessons learned (Curtis, 2017). In the accounting literature action research has most commonly been used in the context of accounting education (e.g. Paisey \& Paisey, 2005; Cunningham, 2008; Hazelton \& Haigh, 2010; McGrath \& Murphy, 2016; Curtis, 2017; Williams, Horner \& Allen, 2019). However, it has also been used in sustainability accounting and reporting research (e.g. Adams \& McNicholas, 2007; Battaglia, Bianchi, Frey, Passetti, 2014). The use of action research in the present study evolved organically through the lead researcher's identification of an opportunity to help try to solve a problem, thus making it the most appropriate research method in the circumstances.

A participant action research (PAR) approach was used, which is where the first two stages of the action research cycle (recognizing the need for change and developing an action plan) are carried out in collaboration between the researcher and the organisation (Susman \& Evered, 1978). The action research was initiated by the lead author (the accountant) in November 2016, when she contacted GAT's Director of Conservation about the possibility of collaborating with the NGO on the project. The accountant had previously been involved with the organisation as a member of their Advisory Council and was aware of the difficulties they had been facing in communicating the value of their biodiverse wildlife corridor plantations to key stakeholders including landowners and government funding bodies. Hence the initial stage of the action research cycle involved identifying the problem (Susman \& Evered, 1978) as being difficulties in communicating value, and recognising that accounting methods may help to resolve this problem (Feger et al., 2018).

Following this initial contact, the project stalled due to the competing work commitments of the participants, and recommenced in May 2018 with a reinitiation of contact by the accountant. The project then progressed with a process of information sharing between the accountant, Director of Conservation and GAT's Senior Restoration Ecologist (the second author of this paper) via email and then face to face meetings, first between the accountant and the Director of Conservation (held in May 2018) and then between the accountant and the ecologist (held in June 2018). Therefore during the process of developing the action plan the participants were simultaneously engaged in a process of sensemaking through dialogue to develop a common language (Feger et al., 2018), which is consistent with the socially constructed nature of action research (Coghlan \& Shani, 2019).

The ecologist agreed that it would be very valuable to use the NIM model to gain an assessment of the biodiversity value of GAT's restoration work. However, he identified issues surrounding the use of secondary data including lack of completeness, and existing available data having been collected over disparate periods. The face to face meeting between the accountant and the ecologist involved a great deal of discussion regarding the viability of the use of the NIM, thus giving rise to the research question addressed in this paper. Having recognised this need for 
change it was agreed that the next step in developing the action plan required a field visit to the site identified for feasibility testing. The site identified was farmland until 2014 and is adjacent to river flats that are prone to flooding, resulting in the landowner's decision to allow GAT to restore the land for the purpose of creating wildlife corridors. A comparison of the original farmland and the restoration area is shown in Figure 3. Due to technical difficulties in accounting for fauna, the feasibility testing focused on flora only.

[Figure 3 about here]

\section{Developing the Action Plan}

In early discussions held in the sterility of the office it was subtly intimated by the ecologist that it was neither feasible nor useful for an NGO with limited resources to implement the NIM as it presently stands. It was explained to the accountant that NGOs undertaking restoration work do not generally collect data about every organism, but instead tend to use proxies as indicators of biodiversity such as structural complexity (McElhinny, Gibbons \& Brack, 2006), soil quality (Agriculture Victoria, 2019), and number of predators (Jørgensen, Xu \& Costanza, 2010). Furthermore, restoration NGOs and environmental scientists require data that can be obtained quickly and easily when dealing with large areas. For example, in developing a system for monitoring and analysing landscape function, Tongway \& Hindley (2004) note that with practice most of their observations take about 5 seconds each to assess in the field. Upon visiting the site (see Figure 4) in August 2019, it was immediately apparent to the accountant why this is necessary, and why implementing the NIM from an NGO user perspective might be problematic. The site was analogical of O'Dwyer's (2004) description of qualitative data: "an attractive but messy nuisance".

[Figure 4 about here]

Implemented in its present form, the NIM could also result in potentially misleading indicators of biodiversity in wildlife corridor plantations. For example, the ecologist explained to the accountant that if one only considers the number of different species in a site, the land identified in Figure 3 would potentially be much more biodiverse than the land identified in Figure 4, simply due to the number of exotic plant (particularly grass) species on the site. However, its ecological value would be much lower as those exotic species are considered to be pests and will cause significant ecological damage over time. The same argument could be made of animal species. This is where the ecological grading undertaken in Stage Two of implementing the NIM is particularly important, but in order to facilitate the evaluation of an appropriate ecological grading the necessary data must be collected at the time of undertaking the initial natural inventory. 
Furthermore, while the requirement of the NIM to record species by total population (Levels 4 $\& 6$ of the NIM) may be appropriate for fauna, it is inappropriate for recording the diversity of species of flora. For example, there may be a single plant that occupies a considerable amount of space, or a number of individual species that occupy a relatively small amount of space. There are also difficulties in classifying a flora species as a single plant, as many seemingly individual plants are actually a single plant connected via root networks (see Figure 5 for such an example).

[Figure 5 about here]

If, as recommended by Jones and Solomon (2013), accountants are to use the data collected by scientists to account for biodiversity, accountants need to adapt accounting models to accommodate that data. The ecologist explained to the accountant that whilst counting numbers of flora species is not met with the same technical difficulties as counting fauna (due to mobility), it is not without its challenges, in addition to being time-consuming, relatively uninformative and potentially misleading when determining the health of a habitat. Scientists have instead developed more efficient and effective means of determining the health of a landscape. Following the aforementioned discussions between the accountant and ecologist it was established that the NIM has some deficiencies in terms of its usefulness for assessing the value of habitat restoration activities from an NGO's perspective. Therefore, the subsequent step in developing the action plan considered ways in which the model could be adapted to be more useful for assessing the value of habitat restoration activities from an NGO's perspective. Based on extensive notes taken during the discussions and extant scientific literature, an adapted pyramid of hierarchical criticality is provided in Figure 6 and discussed in terms of implementing the NIM in further detail below.

[Figure 6 about here]

Level 1 of the model was expanded to include science-based calculations including the structural complexity (McElhinny et al., 2006) of the site. Scientific research suggests that structural complexity such as the presence of trees, shrubs, logs and ground litter is associated with the existence or abundance of fauna (McElhinny et al., 2006), making it a reasonable proxy for biodiversity. At Levels 3-6 species would need to be further classified as being 'native' or 'exotic', which would assist with the ecological grading required in Stage Two of the NIM by overcoming the problem of 'structural mimics': whilst some of the native fauna might be just as happy nesting in an exotic shrub species as they are in a native species of shrub, exotic plant species are often invasive and degrade ecological value in the long term. Finally, due to the difficulties and inadequacy of recording plant species by population, Levels 4 and 6 should alternatively classify flora by abundance, consistent with current scientific methods. It was suggested by the ecologist, in consultation with a botanist with considerable expertise in 
biodiversity that abundance be recorded as a percentage of ground cover measured heuristically as follows:

$$
\begin{aligned}
& +=\text { presence of: }<1 \% \\
& 1=1-5 \% \\
& 2=5-25 \% \\
& 3=25-50 \% \\
& 4=50-75 \% \\
& 5=75-100 \%
\end{aligned}
$$

Following the development of the action plan, which involved adapting the NIM based on recommendations from the ecologist, the next stage of the research required implementation of the action plan to explore whether it can be used to account for biodiverse wildlife corridor plantations from an NGO's perspective.

\section{Implementing the Action Plan}

Implementation of the action plan involved a series of site visits between August and October 2018 to collect the data necessary for the revised NIM. This required the recruitment of a botanist to undertake plant species identification. The involvement of the accountant during this stage of the action research was predominantly as an observer and note taker, but at times required more direct input in terms of ensuring that data collection processes were followed consistently, and no steps missed. Across the site twelve quadrats were identified for comparative and ongoing measurement and management purposes, with their coordinates noted. Quadrats 1-4 were classified by the ecologist as being grassy woodland, quadrats 5-9 as river flats, and Quadrats 10-12 were unrestored grazing land to be used as a control. The results of the Level 2 inventory of listed and protected flora by species and abundance are displayed in Table 1, the Level 3 inventory in Table 2, and the Level 4 inventory for Quadrat 1 is displayed in Table 3.

[Table 1 about here]

[Table 2 about here]

[Table 3 about here]

\section{Observing \& Evaluating the Consequences of the Changes}

Upon making the changes necessary to make the NIM useful for an NGO, it was clear that this model will indeed be beneficial for the ongoing accounting for the biodiverse wildlife corridor plantations, and may also be of use to other organisations undertaking similar projects. For example, the inventory of protected flora will allow us to track their abundance across time and quadrat, which may then be extrapolated to regions. 
Undertaking Level 3 of the revised NIM revealed that by adapting the NIM to classify species according to whether they are native, or exotic provides a much more complete picture than if an inventory of total species without further classification were undertaken. For example, as revealed in Table 2 the majority of species identified in each quadrat are overwhelmingly exotic. Undertaking regular assessments of the NIM will allow GAT to track the proportion of exotic to native species over time and across quadrats, and communicate any changes to landowners.

Finally, the Level 4 inventory shown in Table 3 for Quadrat 1 has been adapted in a couple of very important ways. Firstly, the separation of native and exotic species is very important for an Australian context. Secondly, the use of abundance as a measure rather than population is particularly informative. By using a heuristic measure of abundance, it is easy to see that there is only the presence of native species in the biodiverse wildlife corridor plantation, while exotic species proliferate. This will make the ongoing monitoring and management of these species considerably easier.

\section{Making Sense of and Sharing Lessons Learned}

The accountant and the ecologist are engaged in discussions regarding the outcomes of this first action research cycle and how these will inform the next cycle, thus the sensemaking process is ongoing. However, there are insights and lessons learned from this first cycle of interdisciplinary action research that are of benefit for those in the broader research community. These surround issues in PAR which involves the identification of the problem (recognising a need for change) and developing the action plan, and are set out in the multidirectional cycle provided in Figure 7 below.

Figure 7 about here

Researchers may have identified what they think is are problems and resultant needs for change, but it is imperative that throughout the process they remain open to the possibility that, as with the present study, the apparent solution to a perceived problem is indeed a problem in and of itself. Thus, if our role as action researchers is to bridge the gap between knowledge and practice (Coghlan \& Shani, 2018) and bring about social change (Hazelton \& Haigh, 2010), it is imperative that accountants and ecologists alike are receptive to different ways of seeing and responding to these crises that affect us all.

\section{Opportunities for Future Research}

Future research requires a three-way comparison of the extremes: farmland, restoration areas and native woodland remnants. Assessing fauna diversity is complex and requires specialised equipment. However, ultimately the implementation of the revised model will need to be broadened to include an inventory of other lifeforms, including not only fauna but also insects and bacteria. In the context of the GAT Tasmanian Midlands wildlife corridor plantations project there is potential for the revised NIM to assess all six levels of natural inventory across all three levels of natural capital. 
In the feasibility testing only stage one of the NIM was considered, but further implementation of the revised NIM will require an undertaking of stages two (valuation) and three (reporting) of the model. The latter stages necessitate consultation and collaboration with key stakeholders including landholders and government representatives to determine the effectiveness of the model in terms of discharging accountability and demonstrating environmental stewardship, to explore how the NGO is to be made accountable for their decisions and actions (Unerman \& O'Dwyer, 2006; Cuckston, 2018). Thus it is envisaged that further cycles of the action research will involve interviews with key stakeholders to determine whether the accounting mechanisms presently undertaken meet their information needs and discharge accountability, or whether further adaptations to the model need to be undertaken.

Given the Tasmanian Government's aim for the Tasmanian Midlands to contribute to food security for Tasmanians (Tasmanian Food Security Council, 2012), issues surrounding environmental stewardship and SDG15 (Life on Land) become even more important. Future research should explore existing and potential incentive schemes at a States and Federal level and the possible tensions that arise from differing political ideologies and philosophical underpinnings of stewardship, which have seen little attention in the extant literature (Mathevit et al., 2017). This could extend previous work exploring tax incentives for biodiversity conservation conducted by van Wyk (2010). Furthermore, future research should consider whether the revised NIM has practical replicability in other geographical contexts and geopolitical regions, and the resultant implications this may have for sustainability governance in those areas.

\section{Conclusions, contributions and limitations}

The feasibility testing undertaken suggests that with minor amendments the NIM can be useful for NGOs in assessing the value of their biodiversity conservation and restoration activities, and an amended NIM is proposed for that purpose. The study contributes to the literature in several ways. Despite calls as far back as the early 1990s for the operationalisation of accounting for sustainability (Gray, 1992), the prior research on environmental accounting has been predominantly empirical and descriptive in nature, focusing mainly on the content of external corporate social and environmental reports (Jones, 2003). Despite the potential role accounting and accountants could play in preserving and enhancing biodiversity (Jones \& Solomon, 2013), wildlife issues remain under-researched in the accounting literature (Jones, 2003). Whilst the NIM has been successfully implemented in several international studies (Jones, 2013), this study is the first attempt to operationalise the model in collaboration with a conservation NGO in an Australian setting, as opposed to historic application of NIM. This aligns with calls for accounting, as a productive force (Miller \& Power, 2013) to contribute to conservation and eco-systems management (Ferger \& Mermet, 2017; Cuckston, 2018) ${ }^{2}$. Jones (2013:303) made an urgent "call for arms for individuals, accountants and non-accountants to join together with organisations, governmental and non-governmental organisations to enhance and improve the measurement, recording, valuation and reporting of biodiversity accounting".

\footnotetext{
${ }^{2}$ We are grateful to the anonymous reviewer for highlighting these contributions.
} 
Through the utilisation of action research to inform the refinement of the NIM, and thus the development and implementation of accounting tools to contribute to sustainability efforts, this study is one small attempt to answer this call. 


\section{Appendix}

List of Acronyms (in order of appearance):

GAT - Greening Australia Tasmania

NIM - Natural Inventory Model

SDG - Sustainable Development Goal

NGO - Non-government organisation

CBD - Convention on Biological Diversity

IUCN - International Union for Conservation of Nature

PAR - Participant action research 


\section{References}

Adler, R., Mansi, M., Pandey, R. \& Stringer, C. 2017. United Nations decade on biodiversity: A study of the reporting practices of the Australian mining industry. Accounting, Auditing \& Accountability Journal, 30(8): 1711-1745.

Adams, C. \& McNicholas, P. 2007. Making a difference: Sustainability reporting, accountability and organisational change. Accounting, Auditing \& Accountability Journal, 20(3): 382-402.

Agriculture Victoria. 2019. Soil biological tests. http: / / vro.agriculture.vic.gov.au / dpi / vro / vrosite.nsf/ pages / soilhealth_biology_tests, 25 April, 2019

Akhtar-Khavari, A., MacPherson, E., O’Donnell, E., Woolaston, K., Yates, J., Pelizzon, A. \& Nelson, R. 2019. Why do Australia's environmental laws fail to save our species from extinction? IUCN. https://www.iucn.org/news/world-commission-environmentallaw/201907/why-do-australias-environmental-laws-fail-save-our-species-extinction, 2 April, 2020.

Australian Wildlife Conservancy. 2013. Wildlife extinction crisis. http://www.australianwildlife.org/About-AWC/Wildlife-Extinction-Crisis.aspx, 21 September, 2013

Barnosky, A. D., Hadly, E. A., Bascompte, J., Berlow, E. L., Brown, J. H., Fortelius, M., Getz, W. M., Harte, J., Hastings, A., Marguet, P. A., Martinez, N. D., Mooers, A., Roopnarine, P., Vermeij, G., Williams, J. W., Gillespie, R., Kitzes, J., Marshall, C., Matzke, N., Mindell, D. P., Revilla, E. \& Smith, A. B. 2012. Approaching a state shift in Earth's biosphere. Nature, 486: $52-58$

Barry, J. \& Smith, K. 2008. Landscape, politics, labour and identity: stewardship and the contribution of Green Political Theory. Landscape Research, 33(5): 565-585.

Battaglia, M., Bianchi, L., Frey, M. \& Passetti, E. 2014. Sustainability reporting and corporate identity: action research evidence in an Italian retailing cooperative. Business Ethics: $A$ European Review, 24(1): 52-72.

Bebbington, J. 1997. Engagement, education and sustainability: A review essay on environmental accounting. Accounting, Auditing and Accountability Journal, 10(3): 365-381.

Bebbington, J., Brown, J. \& Frame, B. 2007. Accounting technologies and sustainability assessment models. Ecological Economics, 61(2-3): 224-236.

Bebbington, J., Gray, R., Thomson, I. \& Walters, D. 1994. Accountants' attitudes and environmentally-sensitive accounting. Accounting and Business Research, Spring: 109-120. 
Bebbington, J. \& Unerman, J. 2018. Achieving the United Nations Sustainable Development Goals. Accounting, Auditing and Accountability Journal, 31(1): 2-24.

Carrington, D. 2018. Humans just $0.01 \%$ of all life but have destroyed $83 \%$ of wild mammals - study. The Guardian, https://www.theguardian.com/environment/2018/may/21/humanrace-just-001-of-all-life-but-has-destroyed-over-80-of-wild-mammals-study, 28 September 2018

Coghlan, D. \& Shani, A. B. 2018. Understanding action research. In Lee, B., Saunders, M. N. K. \& Narayanan, V. K. (Eds.), Conducting Action Research for Business and Management Students: 27-40. London: Sage Publications Ltd.

Commonwealth of Australia. 2016. Report on the review of the first five years of Australia's Biodiversity Conservation Strategy 2010-2030.

Commonwealth of Australia. 2017. Australia's strategy for nature (Draft) 2018-2030.

Convention on Biodiversity. 2018. Taking action for biodiversity. https://www.cbd.int/20112020/about, 5 April 2018

Convention on Biodiversity. 2018. Australia. https://www.cbd.int/20112020/actions/countries/au, 5 April 2018

Cuckston, T. 2018. Making accounting for biodiversity research a force for conservation. Social and Environmental Accountability Journal, 38(3): 218-226.

Cunningham, B. M. (2008). Using action research to improve learning and the classroom learning environment. Issues in Accounting Education, 23(1), 1-30.

Curtis, S. M. (2017). Pathway to reform: developing action research capacity in accounting education. Issues in Accounting Education, 32(3), 51-79.

Department of Agriculture, Water and the Environment. 2020. Conservation organisations. https://www.environment.gov.au/land/nrs/getting-involved/conservation-organisations , 12 July 2020.

Department of the Environment and Energy. 2018. Australia's 15 National Biodiversity Hotspots. $\quad$ http://www.environment.gov.au/biodiversity/conservation/hotspots/nationalbiodiversity-hotspots, 5 April 2018.

Dumay, J., La Torre, M. \& Farneti, F. 2018. Developing trust through stewardship: Implications for intellectual capital. Journal of Intellectual Capital, 1469-1930.

Feger, C. \& Mermet, L. 2017. A blueprint towards accounting for the management of ecosystems. Accounting, Auditing \& Accountability Journal, 30(7): 1511-1536. 
Feger, C., Mermet, L., Vira, B., Addison, P. F. E., Barker, R., Birkin, F., Burns, J., C., Cooper, S., Couvet, D., Cuckston, T., Daily, G. C., Dey, C., Gallagher, L., Hails, R., Jollands, S., Mace, G., McKenzie, E., Milne, M., Quattrone, P., Rambaud, A., Russell, S., Santamaria, M. \& Sutherland, W. J. 2018. Four priorities for new links between conservations science and accounting research. Conservation Biology, 33(4): 972-975.

Gray, R. 1992. Accounting for environmentalism: An exploration of the challenge of gently accounting for accountability, transparency and sustainability. Accounting, Organisations and Society, 17(5): 399-425.

Gray, R., Walters, D., Bebbington, J. \& Thompson, I. 1995. The greening of enterprise: an exploration of the (non) role of environmental accounting and environmental accountants in organizational change. Critical Perspectives on Accounting, 6: 211-239.

Greening Australia. 2018. Tasmania Island Ark: Reconnecting The Midlands. https://www.greeningaustralia.org.au/projects/reconnecting-the-midlands/, 5 April 2018

Hazelton, J. \& Haigh, M. (2010). Incorporating sustainability into accounting curricula: lessons learnt from an action research study. Accounting Education: an international journal, 19(12), 159-178.

Hines, R. D. 1989. The sociopolitical paradigm in financial accounting research. Accounting, Auditing and Accountability Journal, 2(1): 52-76.

Hines, R. 1991. On valuing nature. Accounting, Auditing and Accountability Journal, 4(3): 27-29.

Hossain, M. M. 2017. Accounting for biodiversity in Australial: The case of the MurrayDarling Basin Authority. Pacific Accounting Review, 29(1): 2-33.

IUCN. 2020. Members. https://www.iucn.org/regions/oceania/get-involved/members/australia, 2 April 2020

Jones, M. J. 1996. Accounting for biodiversity: A pilot study. British Accounting Review, 28: 281-303

Jones, M. J. 2003. Accounting for biodiversity: operationalising environmental accounting. Accounting, Auditing \& Accountability Journal, 16(5): 762-789.

Jones, M. 2013. Accounting for biodiversity. Routledge, Oxon.

Jones, M. J. \& Solomon, J. F. 2013. Problematising accounting for biodiversity. Accounting, Auditing \& Accountability Journal, 26(5): 668-687.

Jørgensen, S. E., Xu, F. \& Costanza, R. 2010. Handbook of Ecological Health Indicators for Assessment of Ecosystem Health, $2^{\text {nd }}$ Edition. CRC Press. Boca Raton FL. 
Laine, M. 2010. The nature of nature as a stakeholder. Journal of Business Ethics, 96: 73-78.

Lamberton, G. 2005. Sustainability accounting - a brief history and conceptual framework. Accounting Forum, (29): 7-26.

Lawrence, S. R., Botes, V., Collins, E. \& Roper, J. 2013. Does accounting construct the identify of firms as purely self-interested or as socially responsible? Meditari Accountancy Research, 21(2): 144-160.

Lehman, G. 1999. Disclosing new worlds: A role for social and environmental accounting and auditing. Accounting Organizations and Society, 24(3): 217-241.

Lobley, M., Saratsi, E., Winter, M. \& Bullock, J. 2013. Training farmers in agri-environmental management: the case of Environmental Stewardship in lowland England. International Journal of Agricultural Management, 3(1): 12-20.

Mathevet, R., Bousquet, F. \& Raymond, C. M. 2018. The concept of stewardship in sustainability science and conservation. Biological Conservation, 217: 363-370.

McElhinny, C., Gibbons, P. \& Brack, C. 2006. An objective and quantitative methodology for constructing an index of stand structural complexity. Forest Ecology and Management, 235: 54-71.

McGrath, D. \& Murphy, D. (2016). Understanding accounting as a career: an immersion work experience for students making career decisions. Accounting Education, 25(1), 57-87.

Miller, P. \& Power, M. 2013. Accounting, organizing, and economizing: Connecting accounting research and organization theory. The Academy of Management Annals, 7(1): 557-605.

Milne, C. 2006. Green politics. The companion to Tasmanian History. http://www.utas.edu.au/library/companion_to_tasmanian_history/G/Green\%20Politics.htm, 5 April 2018

O'Dwyer, B. 2004. Qualitative data analysis: Illuminating a process for transforming a 'messy' but 'attractive' 'nuisance'. In C. Humphrey \& B. Lee (Eds.), The Real Life Guide to Accounting Research: A Behind-the-Scenes View of Using Qualitative Research Methods: 391-407. Oxford: Elsevier Ltd.

Paisey, C. \& Paisey, N. (2005). Improving accounting education though the use of action research. Journal of Accounting Education, 23, 1-19.

Schaltegger, S., Gibassier, D. \& Zvezdov, D. 2013. Is environmental management accounting a discipline? A bibliometric literature review. Meditari Accountancy Research, 21(1): 4-31. 
Siddiqui, J. 2013. Mainstreaming biodiversity accounting: potential implications for a developing economy. Accounting, Auditing \& Accountability Journal, 26(5): 779-805.

Somekh, B. \& Zeichner, K. (2009). Action research for education reform: remodelling action research theories and practices in local contexts. Educational Action Research, 17(1), 5-21.

Susman, G. I. \& Evered, R. D. 1978. An assessment of the scientific merits of action research. Administrative Science Quarterly, 23(4): 582-603.

Tasmanian Food Security Council (2012.) Food for all Tasmanians: A food security strategy. https://www.dhhs.tas.gov.au/_data/assets/pdf_file/0006/178746/Food_for_all_Tasmanians_A_food_Security_Strategy.pdf, 2 April, 2020.

Tongway, D. \& Hindley, N. 2004. Landscape function analysis: a system for monitoring rangeland function. African Journal of Range \& Forage Science, 21(2): 109-113.

Unerman, J. \& O'Dwyer, B. 2006. Theorising accountability for NGO advocacy. Accounting, Auditing \& Accountability Journal, 19(3): 349-376.

United Nations. 2019. Sustainable development goal 15. https://sustainabledevelopment.un.org/sdg15, 1 September 2019

van Wyk, E. 2010. Tax incentives for biodiversity conservation in the Western Cape. Meditari Accountancy Research, 18(1): 58-75.

West, S., Haider, L. J., Masterson, V., Enqvist, J. P. Svedin, U. \& Tengö, M. 2018. Stewardship, care and relational values. Current Opinion in Environmental Sustainability, 35: 30-38.

Williams, B. R., Horner, C. \& Allen, S. 2019. Flipped v's traditional teaching perspectives in a first year accounting unit: an action research study. Accounting Education, 28(4) 333-352.

Worldometers. 2018. Real time world statistics. http://www.worldometers.info/, 6 April 2018 


\section{List of Figures}

Figure 1. Pyramid of hierarchical criticality

Source: Jones, 2013. Accounting for biodiversity. Routledge, Oxon.

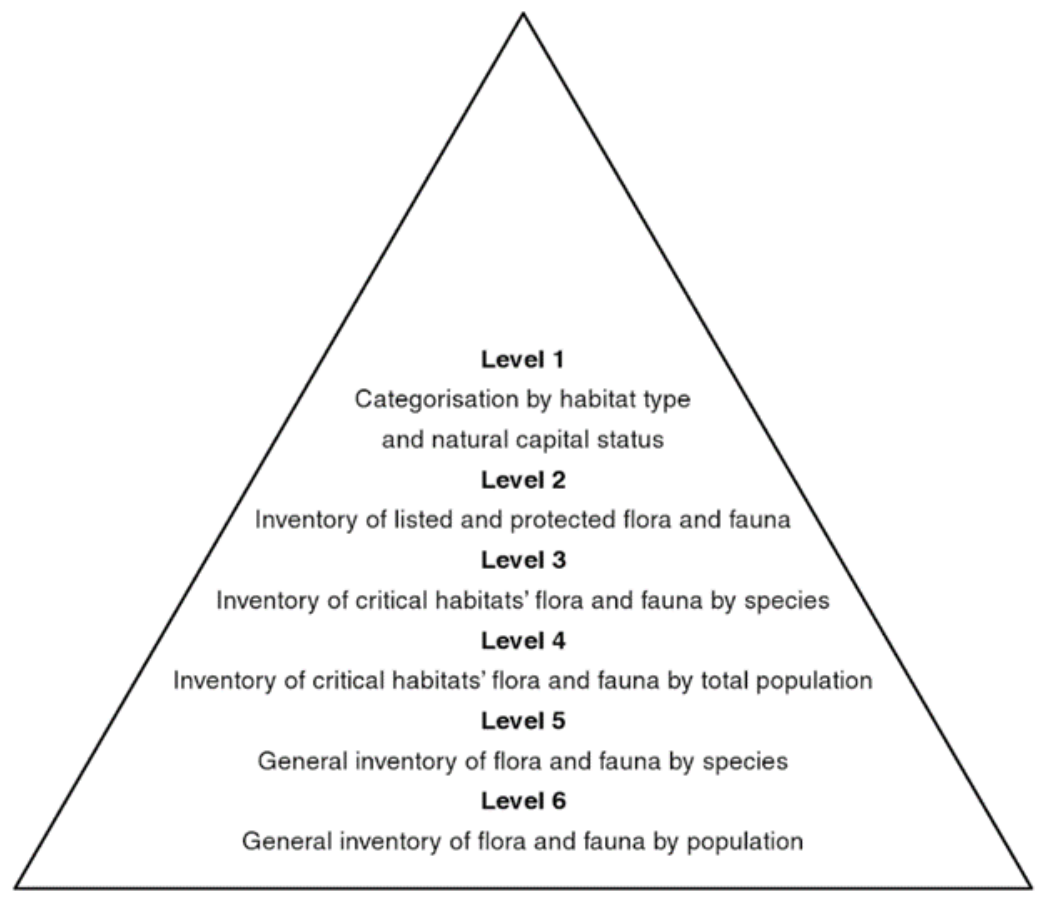

Figure 2. The Action Research Cycle (source: Curtis, 2017)

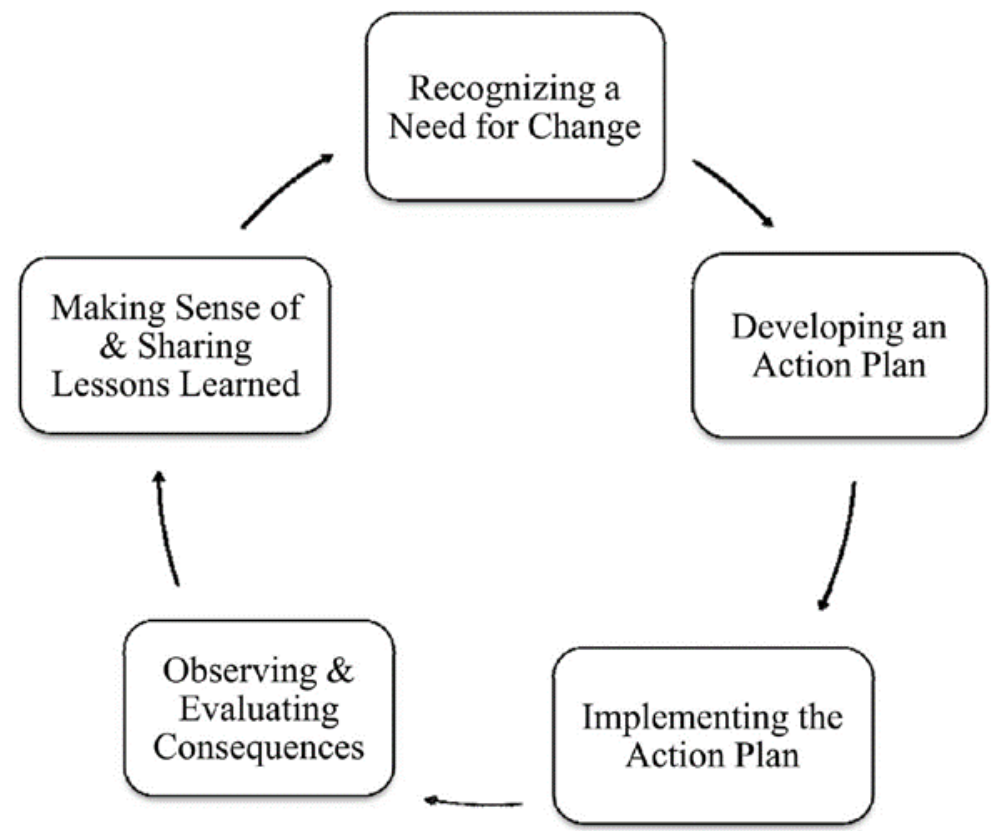


Figure 3. A comparison of existing farmland and the restoration site Source: Author's library

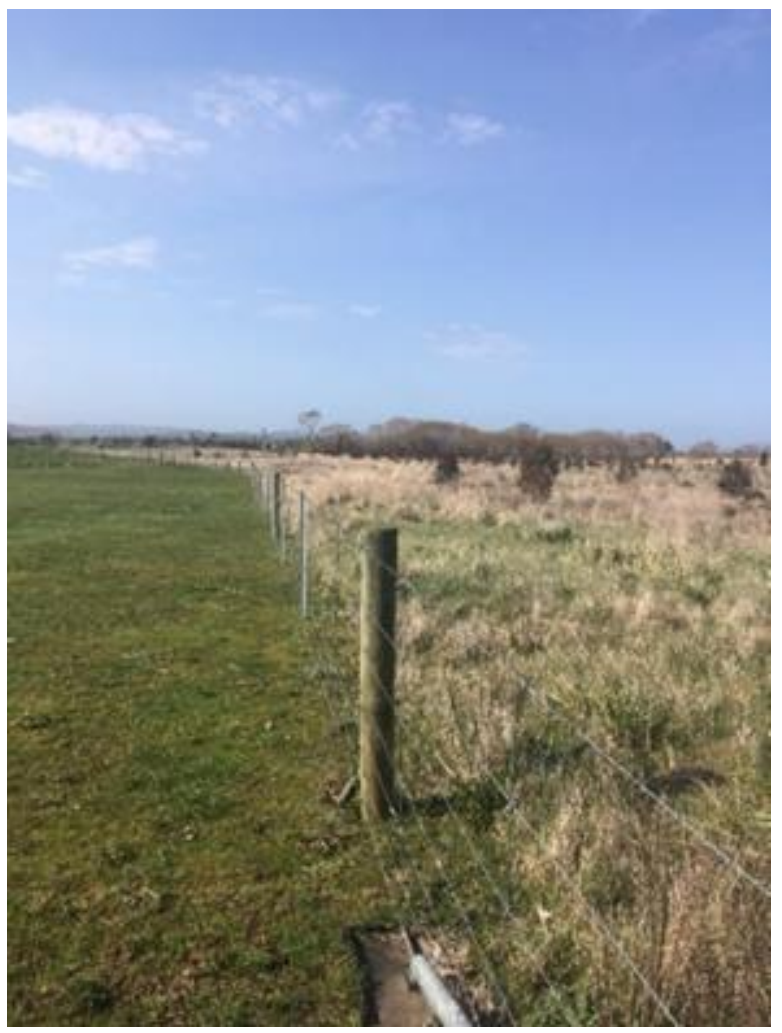

Figure 4. Site identified for feasibility testing Source: Author's library

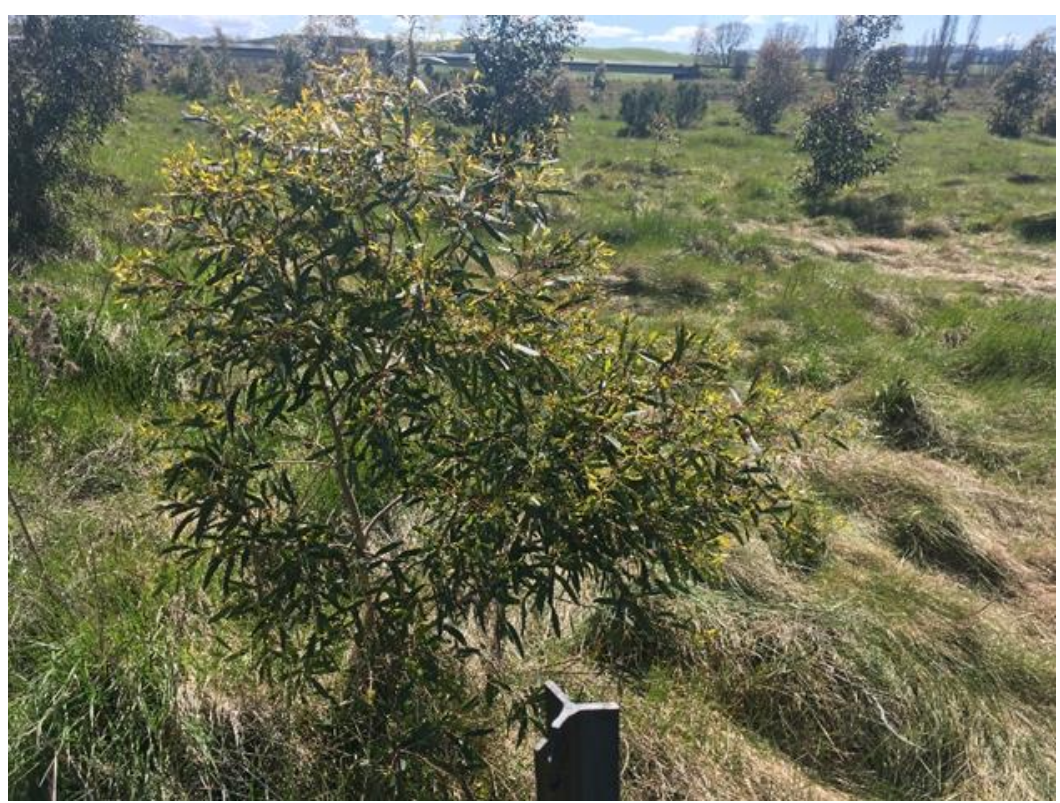


Figure 5. Example of single plant appearing as multiple plants due to root networks Source: Author's library

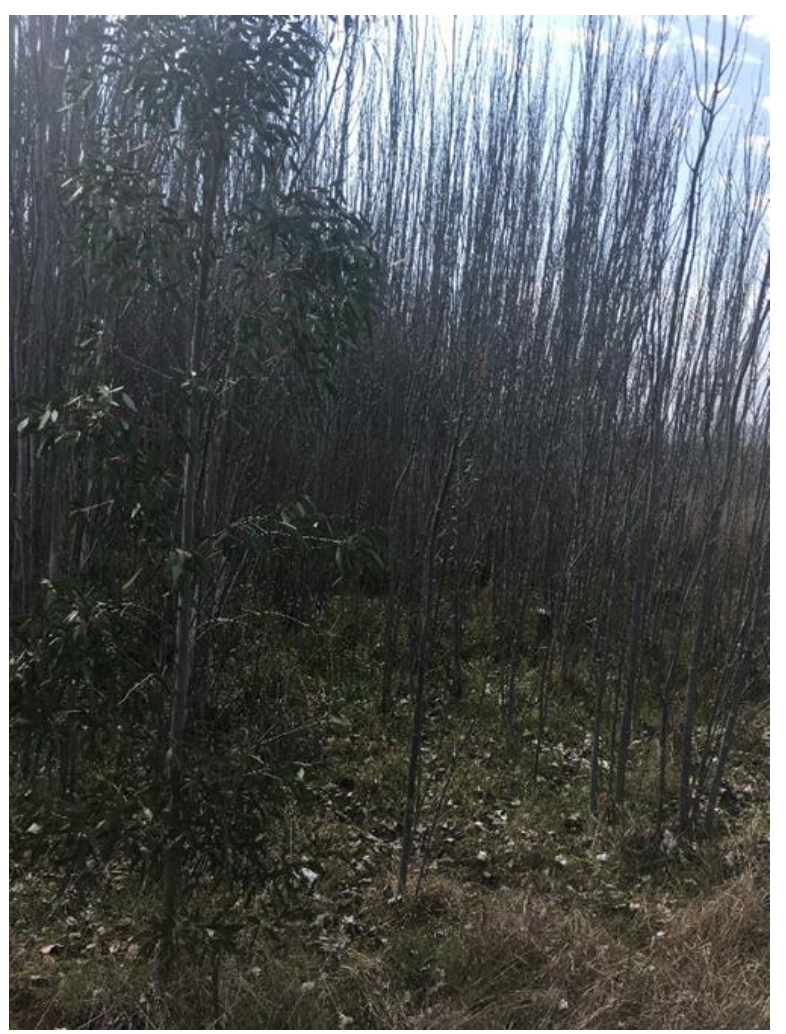

Figure 6. A revised pyramid of hierarchical criticality

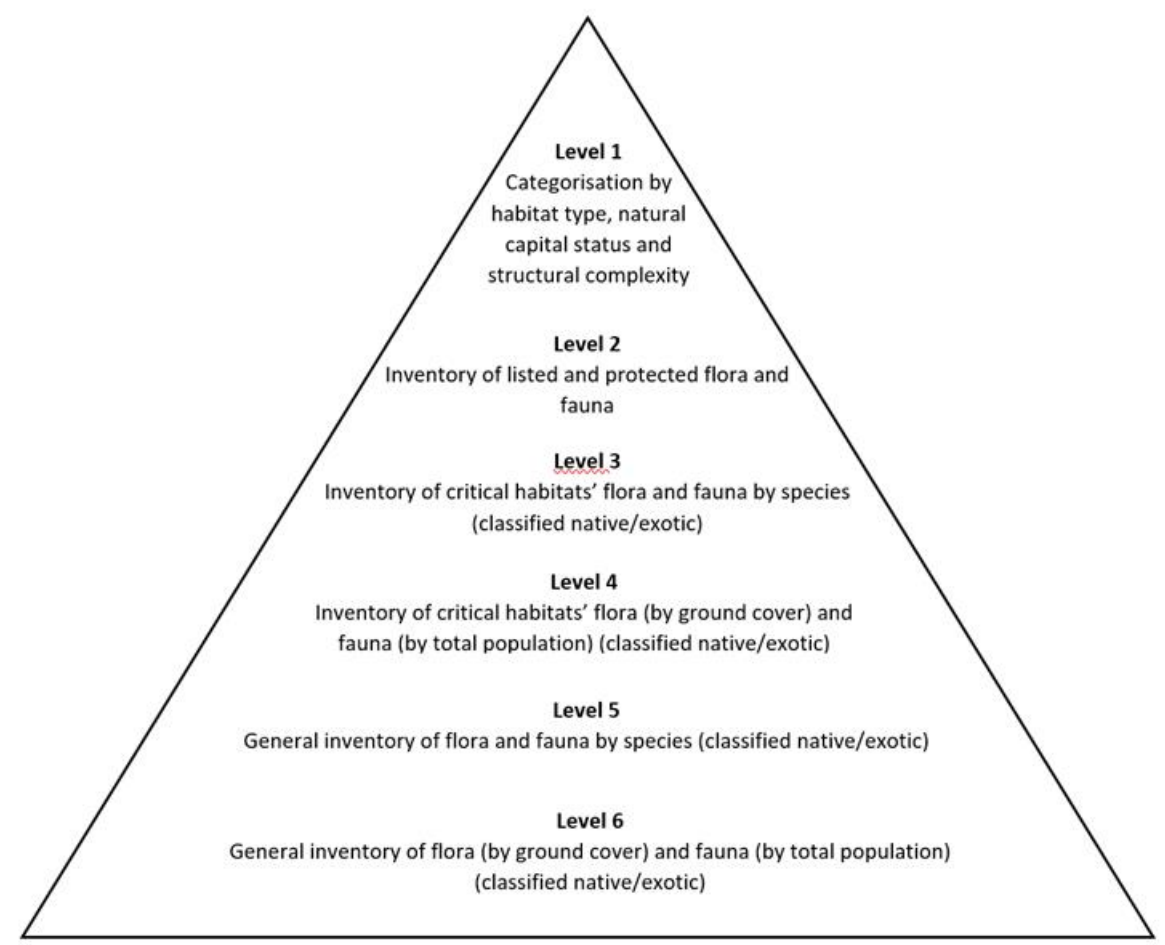


Figure 7. The multidirectional nature of PAR

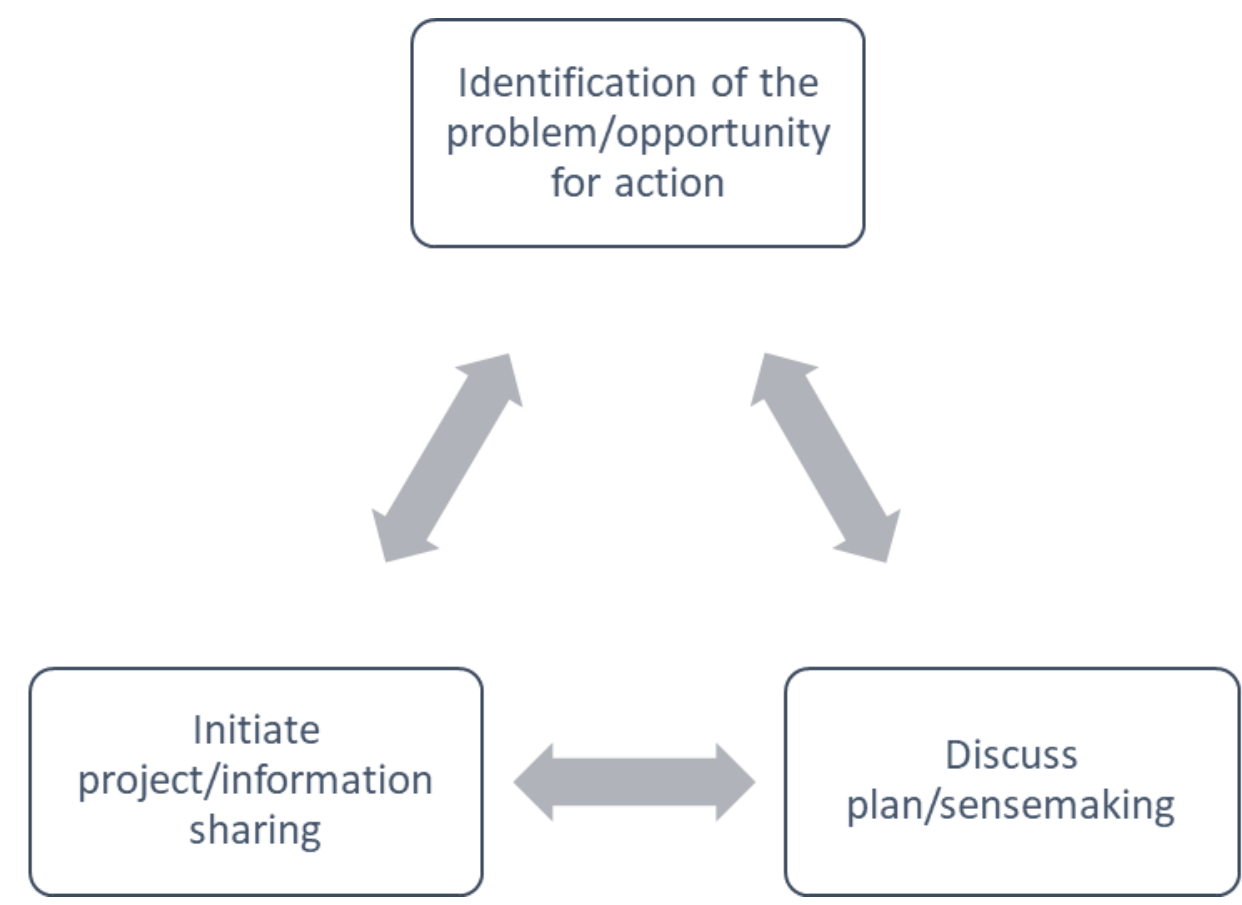




\section{List of Tables}

Table 1. Level 2 inventory of listed and protected flora by species and abundance

\begin{tabular}{|l|l|l|}
\hline Quadrat & Species & Abundance \\
\hline 1 & Eucalyptus ovata & + \\
\cline { 2 - 3 } & Eucalyptus rodwayi & 1 \\
\hline 2 & Nil & \\
\hline 3 & Eucalyptus ovata & 1 \\
\cline { 2 - 3 } & Eucalyptus rodwayi & 1 \\
\hline 4 & Eucalyptus rodwayi & 1 \\
\hline 5 & Hakea macrocarpa & + \\
\hline 6 & Eucalyptus rodwayi & 1 \\
\hline 7 & Eucalyptus rodwayi & + \\
\hline 8 & Acacia melanoxylon & + \\
\cline { 2 - 3 } & Melaleuca pallida & + \\
\hline 9 & Melaleuca pallida & + \\
\hline 10 & Nil & \\
\hline 11 & Nil & \\
\hline 12 & Nil & \\
\hline
\end{tabular}


Table 2. Level 3 inventory of critical habitats' flora by species (classified native/exotic)

\begin{tabular}{|c|c|c|c|c|}
\hline Quadrat & Species Type & $\begin{array}{l}\text { Number of } \\
\text { Species } \\
\text { (Total) }\end{array}$ & $\begin{array}{l}\text { Number of } \\
\text { Species } \\
\text { (Native) }\end{array}$ & $\begin{array}{l}\text { Number of } \\
\text { Species } \\
\text { (Exotic) }\end{array}$ \\
\hline \multirow[t]{7}{*}{1} & Herbs & 11 & 1 & 10 \\
\hline & Grasses & 5 & 2 & 3 \\
\hline & Flowering plants & $9^{3}$ & 1 & 6 \\
\hline & Thistles & 1 & & 1 \\
\hline & Trees & 2 & 2 & \\
\hline & Rushes & 1 & 1 & \\
\hline & Total & 29 & 7 & 20 \\
\hline \multirow[t]{7}{*}{2} & Herbs & 7 & 2 & 5 \\
\hline & Grasses & 6 & 2 & 4 \\
\hline & Flowering plants & 13 & 2 & 11 \\
\hline & Thistles & 1 & & 1 \\
\hline & Shrubs & 1 & & 1 \\
\hline & Rushes & 1 & 1 & \\
\hline & Total & 29 & 7 & 22 \\
\hline \multirow[t]{6}{*}{3} & Herbs & 8 & & 8 \\
\hline & Grasses & 7 & 1 & 6 \\
\hline & Flowering plants & 5 & 1 & 4 \\
\hline & Thistles & 1 & & 1 \\
\hline & Trees & 2 & 2 & \\
\hline & Total & 23 & 4 & 19 \\
\hline \multirow[t]{6}{*}{4} & Herbs & 3 & & 3 \\
\hline & Grasses & 5 & 1 & 4 \\
\hline & Flowering Plants & 3 & & 3 \\
\hline & Thistles & 1 & & 1 \\
\hline & Trees & 1 & 1 & \\
\hline & Total & 13 & 2 & 11 \\
\hline \multirow[t]{6}{*}{5} & Herbs & 2 & & 2 \\
\hline & Grasses & 2 & 1 & 1 \\
\hline & Flowering plants & $11^{4}$ & 1 & 9 \\
\hline & Thistles & 1 & & 1 \\
\hline & Shrubs & 2 & 1 & 1 \\
\hline & Total & 18 & 3 & 14 \\
\hline \multirow[t]{7}{*}{6} & Herbs & $4^{5}$ & & 3 \\
\hline & Grasses & 3 & 2 & 1 \\
\hline & Flowering plants & 6 & & 6 \\
\hline & Thistles & 1 & & 1 \\
\hline & Shrubs & 1 & & 1 \\
\hline & Trees & 1 & & 1 \\
\hline & Rushes & 2 & 2 & \\
\hline
\end{tabular}

\footnotetext{
${ }^{3}$ Due to difficulties in identifying the specific subspecies, the origins of two of the species of flowering plants could not be determined

${ }^{4}$ Due to difficulties in identifying the specific subspecies, the origin of one of the species of flowering plants could not be determined

${ }^{5}$ Due to difficulties in identifying the specific subspecies, the origins of one of the species of herbs could not be determined
} 


\begin{tabular}{|c|c|c|c|c|}
\hline & Total & 18 & 4 & 13 \\
\hline \multirow[t]{6}{*}{7} & Herbs & 2 & & 2 \\
\hline & Grasses & 1 & & 1 \\
\hline & Flowering Plants & 5 & & 5 \\
\hline & Thistles & 1 & & 1 \\
\hline & Trees & 1 & 1 & \\
\hline & Total & 10 & 1 & 9 \\
\hline \multirow[t]{7}{*}{8} & Herbs & 2 & 1 & 1 \\
\hline & Grasses & 2 & 2 & \\
\hline & Flowering plants & 3 & & 3 \\
\hline & Shrubs & 1 & 1 & \\
\hline & Trees & 1 & 1 & \\
\hline & Rushes & 1 & 1 & \\
\hline & Total & 10 & 6 & 4 \\
\hline \multirow[t]{6}{*}{9} & Herbs $^{6}$ & 4 & & 2 \\
\hline & Grasses & 6 & 4 & 2 \\
\hline & Flowering plants & 4 & 1 & 3 \\
\hline & Shrubs & 1 & 1 & \\
\hline & Thistles & 1 & & 1 \\
\hline & Total & 16 & 6 & 8 \\
\hline \multirow[t]{5}{*}{10} & Herbs & 6 & & 6 \\
\hline & Grasses & 3 & & 3 \\
\hline & Flowering plants & 9 & 1 & 8 \\
\hline & Thistles & 1 & & 1 \\
\hline & Total & 19 & 1 & 18 \\
\hline \multirow[t]{5}{*}{11} & Herbs & 3 & & 3 \\
\hline & Grasses & 3 & & 3 \\
\hline & Flowering plants & 11 & & 11 \\
\hline & Thistles & 2 & & 2 \\
\hline & Total & 19 & & 19 \\
\hline \multirow[t]{5}{*}{12} & Herbs & 3 & & 3 \\
\hline & Grasses & 2 & & 2 \\
\hline & Flowering plants & 5 & & 5 \\
\hline & Thistles & 1 & & 1 \\
\hline & Total & 11 & & 11 \\
\hline
\end{tabular}

\footnotetext{
${ }^{6}$ Due to difficulties in identifying the specific subspecies, the origins of two of the species of herbs could not be determined
} 
Table 3. Level 4 inventory of critical habitats' flora (by ground cover) (classified native/exotic)

\begin{tabular}{|c|c|c|c|c|}
\hline \multirow{2}{*}{ Quadrat } & \multicolumn{2}{|l|}{ Native Species } & \multicolumn{2}{|l|}{ Exotic Species } \\
\hline & Species type & Abundance & Species type & Abundance \\
\hline 1 & 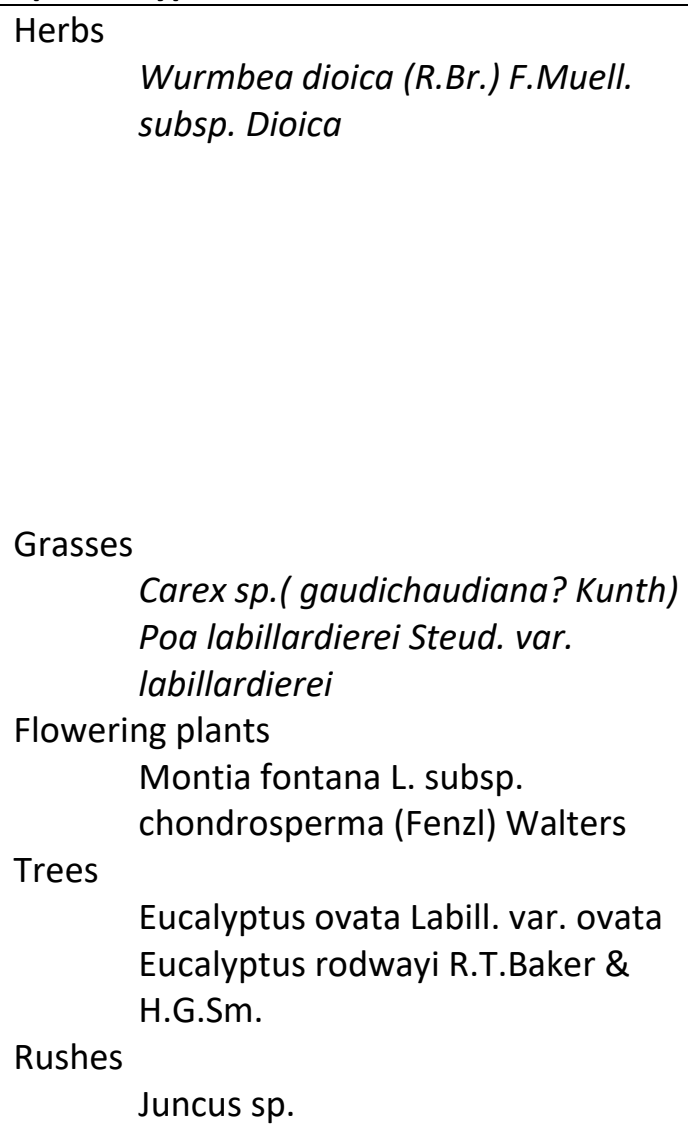 & $\begin{array}{l}+ \\
+\end{array}$ & $\begin{array}{l}\text { Herbs } \\
\text { Acetosella vulgaris Fourr. } \\
\text { Aphanes arvensis L. } \\
\text { Capsella bursa-pastoris (L.) Medik. } \\
\text { Cardamine hirsuta L. } \\
\text { Geranium dissectum L. } \\
\text { Hypochaeris radicata L. } \\
\text { Reseda luteola L. } \\
\text { Romulea rosea (L.) Eckl. var. australis (Ewart) M.P.de Vos } \\
\text { Sanguisorba minor Scop. } \\
\text { Trifolium sp. } \\
\text { Grasses } \\
\text { Bromus hordeaceus L. } \\
\text { Holcus lanatus L. } \\
\text { Phalaris aquatica L. } \\
\text { Flowering plants } \\
\text { Erodium botrys (Cav.) Bertol. } \\
\text { Lactuca sp. } \\
\text { Rumex crispus L. } \\
\text { Rumex sp. } \\
\text { Taraxacum officinale F.H.Wigg. } \\
\text { Tragopogon porrifolius L. subsp. Porrifolius } \\
\text { Thistles } \\
\text { Cirsium vulgare (Savi) Ten. }\end{array}$ & $\begin{array}{l}1 \\
+ \\
1 \\
2 \\
+ \\
1 \\
1 \\
+ \\
2 \\
1 \\
3 \\
+ \\
+ \\
+ \\
+ \\
+ \\
+ \\
+ \\
+ \\
+ \\
+ \\
+\end{array}$ \\
\hline
\end{tabular}

